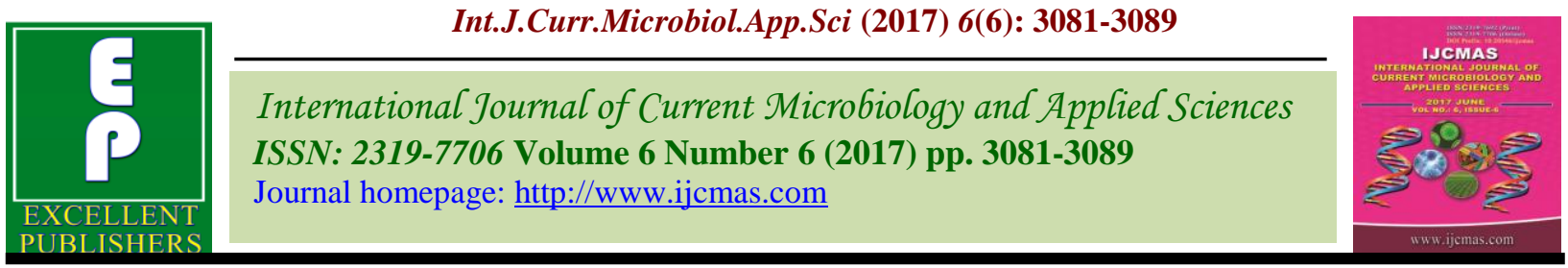

Original Research Article

https://doi.org/10.20546/ijcmas.2017.606.365

\title{
Trend and Growth in Agricultural Credit Portfolio of the Jaipur Central Co-operative Bank: A Case Study
}

\author{
Sarita Meena*, R.C. Kumawat and Vinod Kumar Verma \\ SKN Agriculture University, Jobner, India \\ *Corresponding author:
}

\begin{abstract}
A B S T R A C T
The present investigation was undertaken with a view to studying the (i) share of agricultural credit portfolio to the total credit portfolio of The Jaipur Central Cooperative Bank (ii) Growth in its agricultural credit portfolio over time, and (iii) the overdues of agricultural loan advances and factors affecting them. Renwal branch of

Keywords

Trend,

Growth,

Agricultural credit,

Jaipur Central

Co-operative Bank.

Article Info

Accepted:

29 May 2017

Available Online:

10 June 2017

Phulera tehsil and Bhojpura Kalan Gram Sewa Sahakari Samiti were selected randomly for studying the overdues. All the 77 defaulter farmers belonging to the selected Gram Sewa Sahakari Samiti were considered for studying the overdues. The farmers were categorized into four standard categories namely; marginal, small, semimedium and medium. Both primary and secondary data were collected and used for the purpose. Primary data were collected for the agricultural year 2009-10 through survey method. The trend was significantly positive at 1 per cent level of significance for agricultural, non- agricultural and total credit. Time element accounted for 92.28 per cent variations in the agricultural credit as against 90.34 per cent in the nonagricultural credit advanced by the bank. Agricultural credit, non-agricultural credit and total credit recorded a significant compound growth of 10.32 per cent, 7.50 per cent and 8.40 per cent per annum respectively during the study period. All these growth rates were significant at 1 per cent level of significance. Short term agricultural credit recorded a significant compound growth of 10.46 per cent, as against 8.58 per cent per annum by medium term agricultural credit (both significant at 1 per cent level) during 1996-97 to 2009-10.
\end{abstract}

\section{Introduction}

In India both institutional and noninstitutional agencies are engaged in financing to agriculture. Co-operative banks, Commercial Banks and Regional Rural Banks are the main institutional agencies engaged in financing the agricultural sector. The ground level credit flow by the institutional agencies was of the order of Rs. 69560 crore in 200203 which increased to Rs. 180486 crore in 2005-06. It further increased to Rs. 292437 crore in 2008-09 indicating 4.2 times increase in agricultural credit portfolio over 2002-03. At all India level, in the total flow of institutional credit to agriculture and allied activities, the share of co-operative credit was Rs. 23716 crore in 2002-03, it increased to Rs. 39786 crore in 2005-06, reached at the highest level of Rs. 48258 crore in 2007-08 and then declined to Rs. 36762 crore in the year 2008-09. This signifies that the co- 
operatives are playing a vital role in augmenting agricultural development in the country.

In the state of Rajasthan, too, the co-operative movement was initiated in the beginning of $20^{\text {th }}$ century with three-tier structure. The Rajasthan State Co-operative Bank (RSCB) as the apex bank is primarily responsible for disbursement and use of co-operative credit in the state as a whole. At the district level, the district central co-operative banks are operative. The district central co-operative banks get loans from the state co-operative bank and disburse it to primary agriculture credit societies which operate at the ground level of three-tier co-operative credit structure. These societies provide short-term credit facilities to agricultural sector. The total disbursement of co-operative credit by The Rajasthan State Co-operative Bank to agricultural sector in the state of Rajasthan was Rs. 119879 lakh in 2002-03 and Rs. 339344 lakh in 2009-10 showing an increasing growth in the state's agricultural credit by the bank. The specific objective of the study to estimate the trends and growth in agricultural credit portfolio of the bank over the years.

\section{Materials and Methods}

The Jaipur Central Co-operative Bank was purposely selected for the study because it was the district central co-operative for Jaipur district where in the Agriculture College is situated. This facilitated the researcher to contact the bank branch and the respondent farmers easily moreover, it was one of the largest central co-operative banks of the state. It advanced Rs. 14509.42 lakh of the total agricultural credit (Rs. 310130 lakh) released by the Rajasthan State Cooperative Bank in the state during 2008-09 indicating its importance in the agricultural loan advances. Both primary and secondary data were collected for the study. The secondary data were collected from various records, reports, publications and journals of the Central Cooperative Bank, Apex Bank, RBI and NABARD. Primary data were collected through survey method by personally interviewing the respondents with the help of a pretested schedule developed for the purpose.

\section{Analyses of data}

To estimate the trend and growths of agricultural credit portfolio of the bank over the years, both linear and exponential forms of the function were estimated using the ordinary least squares method and best fit model was selected on the basis of statistical significance of the parameters and goodness of fit.

\section{Trend}

For examining the trend in credit, linear model as specified below was estimated by using the Ordinary Least Squares (OLS) method:

$Y_{t}=a+B_{1} T_{t}+U_{t}$

Where,

$\mathrm{Y}_{\mathrm{t}}=$ Agricultural and non-agricultural credit in year' $t^{\prime}$, $T_{t}=$ Serial number of the year ' $t$ ',

$\mathrm{U}_{\mathrm{t}}=$ Disturbance term with usual assumptions,

$\mathrm{a}$ and $\mathrm{B}_{1}$ are regression coefficients to be estimated.

\section{Compound growth rate}

The compound growth rate was computed by the least squares method of fitting the exponential function $Y_{t}=a b^{t} U_{t}$. By taking logarithms of both sides of the equation, the equation takes the form: 
$\log Y_{t}=\log a+t \log b+\log U_{t}$

Where,

$Y_{t}=$ Amount of agricultural credit in the year' $t$ '

$\mathrm{t}=$ Time element which takes the values 1,2 ,

3, ------, n,

a \& $\mathrm{b}=$ Regression coefficients

$\mathrm{U}_{\mathrm{t}}=$ Disturbance term / Error term
Compound growth rate was worked out as follows:

Compound growth rate $\left(\mathrm{g}_{\mathrm{c}}\right)=(\mathrm{b}-1) \times 100$

$\mathrm{g}_{\mathrm{c}}=$ Compound growth rate in percentage

$\mathrm{b}=$ Antilog of $\log \mathrm{b}$

The standard error (SE) of the compound growth rate was estimated by using the following formula:

$$
\text { S.E. }\left(g_{c}\right)=\frac{100 b}{\log _{10} e} \sqrt{\frac{\left[\sum\left(\log Y_{i}\right)^{2}-\left(\sum \log Y_{i}\right)^{2} / N\right]-\left[\sum T_{i}^{2}-\left(\sum T_{i}\right)^{2} / N\right](\log b)^{2}}{(N-2)\left[\left(\sum T_{i}^{2}\right)-\left(\sum T_{i}\right)^{2} / N\right]}}
$$

Where,

$\log \quad{ }^{\mathrm{e}}=0.4343$

$\mathrm{N}=$ Number of observations.

Student's' $t$ ' test was used to test the significance of the calculated compound growth rate. The significance of growth rate was tested by using the following formula:

$$
\mathrm{t}=\frac{\mathrm{g}_{\mathrm{c}}}{--\mathrm{S.E.}\left(\mathrm{g}_{\mathrm{c}}\right)}
$$

\section{Results and Discussion}

Trend in agricultural, non-agricultural and total credit

The estimates of trend in agricultural, nonagricultural and total credit disbursement by The Jaipur Central Co-operative Bank during 1996-97 to 2009-10 are presented in table 1 .

It is obvious from table 1 that the regression coefficients associated with the time element (t) were positive and highly significant at 1 per cent level of significance for agricultural, non- agricultural and total credit. The value of regression coefficient for time was estimated to be 936.43 for total credit followed by nonagricultural credit (545.99) and agricultural credit (390.45). The estimates of the coefficient of determination $\left(\mathrm{R}^{2}\right)$, a measure of goodness of fit of the regression line to the data ranged from as low as 0.9034 for nonagricultural credit to as high as 0.9298 for total credit indicating that time elements accounted for more than 90 per cent variation in the credit advanced by the ban. The highly significant value of calculated F-statistic also justified the findings that the time element was a significant explanatory variable factor of the variation in credit advanced by the bank during the study period.

\section{Trend in purpose- wise short-term credit}

The estimates of trend and graphical depiction of trend line in purpose wise temporal distribution of short term credits (both agricultural and non agricultural) disbursed by The Jaipur Central Co-operative Bank during 1996-97 to 2009-10 are presented in table 1 and panel of graphs 1 (a) to (c), respectively. The table shows that the regression coefficient for total short term (both agricultural and non-agricultural) credit associated with the time element (t) was 
positive and highly significant at 1 per cent level of significance. The magnitude of regression coefficient for time was estimated to be the highest for total short term credit (899.07) followed by short term nonagricultural credit (539.51), short term agricultural credit (359.55), oil seed production (288.84) and DTP (56.86) (Table 2 ). It is obvious from the table that in case of short term credit for oil seed production the regression coefficient for time was highly significant at 1 per cent level of significance. For DTP credit it was significant at 5 per cent level of significance. In case of Krishak Mitra Yojana the regression for time was estimated to be non-significant. The estimates of the coefficients of determination $\left(\mathrm{R}^{2}\right)$ ranged from as low as 0.0084 for Krishak Mitra Yojana to as high as 0.9345 for oil seed production indicating that the time element alone explained 8.4 per cent to 93.45 per cent variation in the credit advanced by the bank. The highly significant value of calculated Fstatistic also justified the findings that the time element was a significant explanatory variable for the variation in credit advanced by the bank during the study period.

\section{Trend in purpose- wise medium-term credit}

The estimates of trend in purpose- wise distribution of medium term credit disbursed by The Jaipur Central Co-operative Bank during 1996-97 to 2009-10 are presented in Table 3 that shows the regression coefficient for medium term (both agricultural and nonagricultural) credit associated with the time element $(\mathrm{t})$ was positive and highly significant at 1 per cent level of significance for purpose wise distribution of medium term credit. The magnitude of regression coefficient for time was estimated to be the highest for total medium term credit (37.37) followed by medium term agricultural credit (30.88), oil seed processing (10.00), dairy and poultry (6.79), medium term non-agricultural credit
(6.48), sprinkler and drip irrigation system (5.65) and repairs of tractor and machinery (4.37). It is obvious from the table that in case of medium term credit for tractor and machinery the regression coefficient for time was highly significant 1 per cent level of significance. For tractor and machinery repairs it was significant at 1 per cent level of significance. In case of repairs of tube-wells, the regression coefficient for time was estimated to be non-significant. The trends in different types of medium term credits are also presented graphically in fig. 1 (a) through 1 (c). The estimates of the coefficient of determination $\left(\mathrm{R}^{2}\right)$ ranged from as low as 0.0754 for repairs of tube-wells to as high as 0.6106 for repairs of tractor and machinery indicating that the time element alone explained 7.54 per cent to 38.00 per cent variation in the credit advanced by the bank. The highly significant value of calculated Fstatistic also justified the findings that the time element was a significant explanatory variable for the variation in credit advanced by the bank during the study period.

\section{Growth of credit portfolio}

Both linear as well as compound growth rates were estimated. These growth rates were compared on the basis of their standard errors and coefficients of determination $\left(\mathrm{R}^{2}\right)$. The smaller magnitude of standard errors and generally high magnitude of $\mathrm{R}^{2}$ for the exponential function established the strong evidence for statistical reliability of the estimates of compound growth rates. Considering the above facts compound growth rates were selected for further discussion.

\section{Growth of agricultural and non-} agricultural credit

The estimated compound growth rates of agricultural and non- agricultural credit disbursed by The Jaipur Central co-operative 
Bank during 1996-97 to 2009-10 are presented in table 4 . The table reveals that agricultural credit recorded a significant compound growth of 10.32 per cent per annum during the study period. Nonagricultural credit, on the other hand, recorded a significant compound growth rate of 7.50 per cent per annum during the same period. Both agricultural and non-agricultural credit combined together recorded a compound growth rate of 8.40 per cent per annum during the period. A perusal of the table reveals that the magnitude of growth rate for agricultural credit was higher than that for non-agricultural credit during the study period. All these growth rates were significant at 1 per cent level of significance.

\section{Growth of term- wise non-agricultural credit}

Table 5 shows the estimated compound growth rates of term wise non-agricultural credit disbursed by The Jaipur Central Cooperative Bank during 1996-97 to 2009-10. The table exhibits that short term nonagricultural credit recorded a significant compound growth of 7.49 per cent per annum at 1 per cent level of significance during 1996-97 to 2009-10. Medium term nonagricultural credit, on the other hand, recorded a non-significant growth rate of 6.43 per cent per annum during the same period. Both short term and medium term nonagricultural credit combined together recorded a significant (significant at 1 per cent level) compound growth rate of 7.50 per cent during the period. A scrutiny of the table reveals that the growth in total nonagricultural credit ( 7.50 per cent per annum) was mainly due to growth in short-term nonagricultural credit (7.49 per cent). The role of growth of medium term non-agricultural credit in the growth of total non-agricultural credit was negligible.

Growth of purpose-wise short-term credit
The short term agricultural credit recorded a significant compound growth rate of 10.46 per cent per annum at 1 per cent level of significance during the period 1996-97 to 2009-10 (Table 6). Short-term nonagricultural credit, on the other hand, recorded a significant growth rate of 7.49 per cent per annum during the same period - the growth rate being significant at 1 per cent level of significance. Component wise only short-term credit for oilseeds production recorded a significant compound growth of 9.78 per cent per annum during the period. The growths in short term credit for Krishak Mitra Yojana and DTP were estimated to be non-significant. Short term agricultural credit and short term non-agricultural credit jointly recorded a significant compound growth rate of 8.38 per cent per annum during the period. A perusal of the table reveals that the magnitude of growth rate for short term agricultural credit was higher (10.46 per cent per annum) than that for short term nonagricultural credit (8.38 per cent per annum) during the study period.

\section{Growth of purpose wise medium-term credit}

The estimated compound growth rates of purpose wise medium term agricultural credit disbursed by The Jaipur Central Co-operative Bank are presented in table 3. The table reveals that total medium term credit recorded a significant compound growth rate of 7.90 per cent per annum during the period.

As regards medium term agricultural credit, it registered a significant compound growth rate of 8.58 per cent per annum during the same period. Medium term non-agricultural credit, on the other hand, registered a non-significant compound growth rate of 6.43 per cent per annum.

Medium term credit advanced for different 
purposes also recorded significant growth except for repairs of tube wells. Medium term loan for oil seeds processing recorded a growth rate of 13.42 per cent per annum which was significant at 1 per cent level of significance. Credit advanced for dairy and poultry recorded a significant annual compound growth rate of 6.86 per cent followed by tractor and machinery (5.68 per cent) and sprinkler and drip irrigation system (5.01, significant at 1 per cent level). A perusal of the table reveals that the medium term credit for non-agricultural purposes did not record any significant growth during the study period (Table 7).

Table.1 Estimated trend in agricultural, non-agricultural and total credit disbursed by The Jaipur Central Co-operative Bank during 1996-97 to 2009-10

\begin{tabular}{|c|c|c|c|c|}
\hline Type of credit & $\begin{array}{c}\text { Intercept } \\
\text { (a) }\end{array}$ & $\begin{array}{c}\text { Regression } \\
\text { coefficient (B) }\end{array}$ & $\mathbf{R}^{2}$ & $\begin{array}{c}\text { F-statistic } \\
\text { calculated }\end{array}$ \\
\hline (a) Agricultural credit & $\begin{array}{c}-514.04 * * \\
(277.49)\end{array}$ & $\begin{array}{c}390.45^{* * *} \\
(32.59)\end{array}$ & 0.9228 & 143.54 \\
\hline (b) Non-agricultural credit & $\begin{array}{c}-416.18 \\
(438.96)\end{array}$ & $\begin{array}{c}545.99 * * * \\
(51.55)\end{array}$ & 0.9034 & 112.17 \\
\hline (c) Total credit (a)+ (b) & $-930.22^{*}$ & $\begin{array}{c}936.43 * * * \\
(74.34)\end{array}$ & 0.9298 & 158.68 \\
& $(632.98)$ & $(7.3)$ & \\
\hline
\end{tabular}

Figures in parentheses are the standard errors of the regression coefficients

***, ** and * denote significance at 1 per cent, 5 per cent and 10 per cent

Table.2 Estimated trends in purpose-wise short-term credit advanced by the Jaipur central cooperative bank during 1996-97 to 2009-10

\begin{tabular}{|l|c|c|c|c|}
\hline Type of credit & $\begin{array}{c}\text { Intercept } \\
\text { (a) }\end{array}$ & $\begin{array}{c}\text { Regression } \\
\text { coefficient } \\
\text { (B) }\end{array}$ & $\mathbf{R}^{2}$ & $\begin{array}{c}\text { F-statistic } \\
\text { calculated }\end{array}$ \\
\hline $\begin{array}{l}\text { (a) Short term agricultural } \\
\text { credit }\end{array}$ & & & & \\
\hline (i) Oil seed production & $\begin{array}{c}-403.26^{*} \\
(188.01)\end{array}$ & $\begin{array}{c}288.84^{* * *} \\
(22.08)\end{array}$ & 0.9345 & 171.12 \\
\hline (ii) Krishak Mitra Yojana & $\begin{array}{c}103.94 \\
(129.09)\end{array}$ & $\begin{array}{c}5.42 \\
(20.80)\end{array}$ & 0.0084 & 0.07 \\
\hline $\begin{array}{l}\text { (iii) Short-term agricultural } \\
\text { credit for DTP }\end{array}$ & $\begin{array}{c}100.99 \\
(146.93)\end{array}$ & $\begin{array}{c}56.86^{*} \\
(23.68)\end{array}$ & 0.4189 & 5.77 \\
\hline Total of (i) to (iii) & $\begin{array}{c}-542.56^{* *} \\
(252.97)\end{array}$ & $\begin{array}{c}359.55^{* * *} \\
(29.71)\end{array}$ & 0.9243 & 146.46 \\
\hline $\begin{array}{l}\text { (b) Short term non-agricultural } \\
\text { credit }\end{array}$ & -422.08 & $539.51^{* * *}$ & 0.8928 & 99.94 \\
\hline $\begin{array}{c}\text { (c) Total short term credit } \\
\text { (a+b) }\end{array}$ & $-959.52)$ & $(53.97)$ & & 132.36 \\
\hline
\end{tabular}

Figures in parentheses are the standard errors of the regression coefficients $* * *, * *$ and $*$ denote significance at 1 per cent, 5 per cent and 10 per cent 
Table.3 Estimated trends in purpose-wise medium-term credit advanced by The Jaipur Central Co-operative Bank during 1996-97 to 2009-10

\begin{tabular}{|c|c|c|c|c|}
\hline Type of credit & Intercept (a) & $\begin{array}{c}\text { Regression } \\
\text { coefficient }(B)\end{array}$ & $\mathbf{R}^{2}$ & $\begin{array}{l}\text { F-statistic } \\
\text { calculated }\end{array}$ \\
\hline \multicolumn{5}{|l|}{$\begin{array}{l}\text { (a) Medium term agricultural } \\
\text { credit }\end{array}$} \\
\hline (i) Oil seed processing & $\begin{array}{l}-6.86 \\
(52.43)\end{array}$ & $\begin{array}{l}10.00^{*} \\
(6.16)\end{array}$ & 0.1801 & 2.64 \\
\hline (ii) Dairy and poultry & $\begin{array}{c}20.37 \\
(21.31)\end{array}$ & $\begin{array}{l}6.79 * \\
(2.50)\end{array}$ & 0.3800 & 7.35 \\
\hline (iii) Tractor and machinery & $\begin{array}{l}10.12 \\
(8.58) \\
\end{array}$ & $\begin{array}{c}4.37 * * * \\
(1.01)\end{array}$ & 0.6106 & 18.82 \\
\hline (iv) Sprinkler and drip & $\begin{array}{c}42.44 \\
(31.40)\end{array}$ & $\begin{array}{c}5.65 \\
(5.06)\end{array}$ & 0.1348 & 1.24 \\
\hline (v) Repair of Tube-well & $\begin{array}{c}16.22 \\
(10.50)\end{array}$ & $\begin{array}{c}1.22 \\
(1.23)\end{array}$ & 0.0754 & 0.98 \\
\hline Total of (i) to (v) & $\begin{array}{c}28.64 \\
(101.01)\end{array}$ & $\begin{array}{l}30.88^{*} \\
(11.86)\end{array}$ & 0.3608 & 6.77 \\
\hline $\begin{array}{l}\text { (b) Medium term non- } \\
\text { agricultural credit }\end{array}$ & $\begin{array}{c}5.90 \\
(36.04)\end{array}$ & $\begin{array}{l}6.48 * \\
(4.23)\end{array}$ & 0.1633 & 2.34 \\
\hline $\begin{array}{l}\text { (c) Total medium term credit } \\
(a+b)\end{array}$ & $\begin{array}{c}34.42 \\
(132.50)\end{array}$ & $\begin{array}{c}37.37 * * * \\
(15.56)\end{array}$ & 0.3246 & 5.77 \\
\hline
\end{tabular}

Figures in parentheses are the standard errors of the regression coefficients $* * *, * *$ and $*$ denote significance at 1 per cent, 5 per cent and 10 per cent

Table.4 Compound growth rates of agricultural and non-agricultural credit disbursed by The Jaipur Central Co-operative Bank during 1996-97 to 2009-10

(Per cent per annum)

\begin{tabular}{|l|c|c|c|c|}
\hline Type of credit & $\begin{array}{c}\text { Compound } \\
\text { growth rate }\end{array}$ & $\begin{array}{c}\text { Standard } \\
\text { error }\end{array}$ & t-value & $\mathbf{R}^{\mathbf{2}}$ \\
\hline (a) Agricultural credit & $10.32^{* * *}$ & 0.0093 & 10.53 & 0.9023 \\
\hline (b) Non-agricultural credit & $7.50^{* * *}$ & 0.0361 & 17.03 & 0.9603 \\
\hline (c) Total credit (a)+(b) & $8.40^{* * *}$ & 0.0053 & 15.09 & 0.9500 \\
\hline
\end{tabular}

*** Significant at 1 per cent level of significance

Table.5 Compound growth rates of term-wise non-agricultural credit advanced by The Jaipur Central Co-operative Bank during 1996-97 to 2009-10

(Per cent per annum)

\begin{tabular}{|l|c|c|c|c|}
\hline $\begin{array}{l}\text { Type of Non-Agricultural } \\
\text { Credit }\end{array}$ & $\begin{array}{c}\text { Compound } \\
\text { growth rate }\end{array}$ & $\begin{array}{c}\text { Standard } \\
\text { error }\end{array}$ & t-value & $\mathbf{R}^{2}$ \\
\hline $\begin{array}{c}\text { (a) Short term non-agricultural } \\
\text { credit }\end{array}$ & $7.49^{* * *}$ & 0.0044 & 16.10 & 0.9558 \\
\hline $\begin{array}{c}\text { (b) Medium term non- } \\
\text { agricultural credit }\end{array}$ & 6.43 & 0.0444 & 1.40 & 0.1408 \\
\hline $\begin{array}{l}\text { (c) Total non-agricultural credit } \\
\text { (a+b) }\end{array}$ & $7.50^{* * *}$ & 0.0361 & 17.03 & 0.9603 \\
\hline
\end{tabular}

*** Significant at 1 per cent level of significance 
Table.6 Compound growth rates of purpose-wise Short-term credit advanced by The Jaipur Central Co-operative Bank during 1996-97 to 2009-10

(Per cent per annum)

\begin{tabular}{|l|c|c|c|c|}
\hline Type of credit & $\begin{array}{c}\text { Compound } \\
\text { growth rate }\end{array}$ & $\begin{array}{c}\text { Standard } \\
\text { error }\end{array}$ & t-value & $\mathbf{R}^{\mathbf{2}}$ \\
\hline $\begin{array}{l}\text { (a) Short term agricultural } \\
\text { credit }\end{array}$ & & & & \\
\hline (i) Oil seed production & $9.78^{* * *}$ & 0.0075 & 12.31 & 0.9267 \\
\hline (ii) Krishak Mitra Yojana & 7.02 & 0.0614 & 1.10 & 0.1322 \\
\hline $\begin{array}{l}\text { (iii) Short-term agricultural } \\
\text { credit for DTP }\end{array}$ & 7.16 & 0.0438 & 1.57 & 0.2377 \\
\hline Sub Total of (a) & $10.46^{* * *}$ & 0.0088 & 11.26 & 0.9137 \\
\hline $\begin{array}{l}\text { (b) Short term non- } \\
\text { agricultural credit }\end{array}$ & $7.49^{* * *}$ & 0.0044 & 16.10 & 0.9558 \\
\hline $\begin{array}{l}\text { (c) Total short term credit } \\
\text { (a+b) }\end{array}$ & $8.38^{* * * *}$ & 0.0052 & 15.45 & 0.9521 \\
\hline
\end{tabular}

*** Significant at 1 per cent level of significance

Table.7 Compound growth rates of purpose-wise medium-term credit advanced by The Jaipur Central Co-operative Bank during 1996-97 to 2009-10

(Per cent per annum)

\begin{tabular}{|l|c|c|c|c|}
\hline Type of credit & $\begin{array}{c}\text { Compound } \\
\text { growth rate }\end{array}$ & $\begin{array}{c}\text { Standard } \\
\text { error }\end{array}$ & t-value & $\mathbf{R}^{2}$ \\
\hline $\begin{array}{c}\text { (a) Medium term } \\
\text { agricultural credit }\end{array}$ & & & & \\
\hline (i) Oil seed processing & $13.42^{* * *}$ & 0.0371 & 3.39 & 0.4895 \\
\hline (ii) Dairy and poultry & $6.86^{* * *}$ & 0.0167 & 3.96 & 0.5662 \\
\hline $\begin{array}{c}\text { (iii) Tractor and } \\
\text { machinery }\end{array}$ & $5.68^{* * *}$ & 0.0113 & 4.86 & 0.6634 \\
\hline (iv) Sprinkler and drip & $5.01^{*}$ & 0.0249 & 11.96 & 0.3244 \\
\hline (v) Repair of Tube-well & 3.19 & 0.0214 & 1.462 & 0.1513 \\
\hline Sub Total of (a) & $8.58^{* * *}$ & 0.0174 & 4.71 & 0.6493 \\
\hline $\begin{array}{l}\text { (b) Medium term non- } \\
\text { agricultural credit }\end{array}$ & 6.43 & 0.0444 & 1.40 & 0.1408 \\
\hline $\begin{array}{l}\text { (c) Total medium term } \\
\text { credit (a+ b) }\end{array}$ & $7.90^{* * * *}$ & 0.0169 & 4.48 & 0.0170 \\
\hline
\end{tabular}

*** Significant at 1 per cent level of significance

* Significant at 10 per cent level of significance

From the ongoing discussion it may be concluded that all types of credit, ranging for agricultural to non-agricultural or short term agricultural/ non-agricultural credit to medium term agricultural/ non- agricultural credit, recorded significant growth and trend, in their magnitude overtime. It was noted that the growth in agricultural credit was more (10.32 per cent) than that in non- agricultural credit (7.50 per cent) during the study period. Similarly, the growth in short term agricultural / non agricultural credit was more 
than that in medium term agricultural / nonagricultural credit.

\section{References}

Cardoso, D.F.; Teixeria, E.C., Gurgel, A.C., Castro, E.R. 2011, Effects of government intervention via rural credit subsidy on economic growth and welfare of Brazilian regions. Indian Journal of Agricultural Marketing, 25 (3): 41.

Das, D., 2000, "Co-operatives Banking in Arunchal Pradesh; A Case Study". Indian Cooperative Review, 38 (1); 4853.

Godgil, M.V. 1986, "Agricultural credit in India - A review of performance and polices India. Journal of Agricultural Economics, 41 (3): 282-309.

Indira Devi, P.; Thomas, E.C. and Tomas, K. Jerry, 1991, "Growth and Performance of Cooperatives Agricultural Credit in Kerala" Indian Co-operatives Review, 28-29; 237-336.

Malik, D.P.; Singh, S.N. and Dhanda Sunil, 2005, "Growth and performance of primary Agricultural Credit Societies An Appraisal". Indian Journal of Agricultural Economics, 60 (3); 405406.

Sharma, R.C. 1984, "An Economic Study of Regional Rural Banks. A Case Study of Jaipur-Nagaur Aanchalik Gramin Bank". M.Sc. (Ag.) Economics Unpublished, Thesis, Sukhadia University, Campus-Jobner, pp. 66-77.

Sharma, V.K., 2008, Institutional financing and determinants of agricultural overdues. IUP Journal of Agricultural Economics, 5 (4); 67-84.

Sidhu, R.S.; Sidhu, J.S. and Kumar, S., 2006, "Factors affecting fertilizers consumption in India with special Reference to Punjab state". Ministry of Agriculture Government of India (under Agro-Economic Research Centre, New Delhi.

Singh, P.N.; Singh, S.K.; Singh, M.K.; Singh, A.K. and Anand 2002, "Structure and Function of Primary Agricultural Cooperative Credit Society: A case study". Indian Journal of Agricultural Economics, 57 (3); 590-591.

\section{How to cite this article:}

Sarita Meena, R.C. Kumawat and Vinod Kumar Verma. 2017. Trend and Growth in Agricultural Credit Portfolio of the Jaipur Central Co-operative Bank: A Case Study. Int.J.Curr.Microbiol.App.Sci. 6(6): 3081-3089. doi: https://doi.org/10.20546/ijcmas.2017.606.365 